\title{
QUALIFICATION OF THE NIPPON INSTRUMENTATION FOR USE IN MEASURING MERCURY AT THE DEFENSE WASTE PROCESSING FACILITY
}

R.N. Mahannah

T.B. Edwards

October 2010

Applied Computational Engineering and Statistics Savannah River National Laboratory

Aiken, SC 29808

This document was prepared in conjunction with work accomplished under Contract No. DE-AC09-08SR22470 with the U.S. Department of Energy.

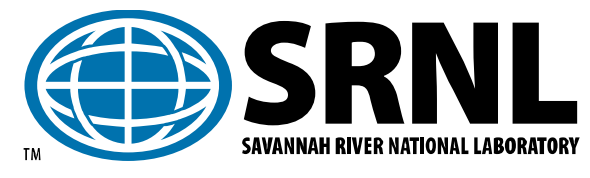


SRNL-STI-2010-00612

Revision 0

\section{DISCLAIMER}

This work was prepared under an agreement with and funded by the U.S. Government. Neither the U.S. Government or its employees, nor any of its contractors, subcontractors or their employees, makes any express or implied: 1 . warranty or assumes any legal liability for the accuracy, completeness, or for the use or results of such use of any information, product, or process disclosed; or 2. representation that such use or results of such use would not infringe privately owned rights; or 3. endorsement or recommendation of any specifically identified commercial product, process, or service. Any views and opinions of authors expressed in this work do not necessarily state or reflect those of the United States Government, or its contractors, or subcontractors.

This document was prepared in conjunction with work accomplished under Contract No. DE-AC09-08SR22470 with the U.S. Department of Energy. 
SRNL-STI-2010-00612

Revision 0

\section{REVIEWS AND APPROVALS}

\section{AUTHORS:}

R. N. Mahannah, Waste Laboratory Services

Date

Savannah River Remediation

T. B. Edwards, Applied Computational Engineering and Statistics

Date

Savannah River National Laboratory

\section{TECHNICAL REVIEWERS:}

D. R. Best, Process Technology Programs

Date

Savannah River National Laboratory

E. P. Shine, Applied Computational Engineering and Statistics Date

Savannah River National Laboratory

\section{APPROVERS:}

P. L. Lee, Manager, Applied Computational Engineering and Statistics Date Savannah River National Laboratory

C. C. Herman, Manager, Process Technology Programs

Date

Savannah River National Laboratory

S. L. Marra, Manager,

Date

Environmental \& Chemical Process Technology Research Programs

Savannah River National Laboratory

M. J. Hart, Manager, Waste Laboratory Services

Date

Savannah River Remediation

J.E. Occhipinti, Manager, Waste Solidification Engineering

Date

Savannah River Remediation 


\section{EXECUTIVE SUMMARY}

The Nippon Mercury/RA-3000 system installed in 221-S M-14 has been qualified for use. The qualification was a side-by-side comparison of the Nippon Mercury/RA-3000 system with the currently used Bacharach Mercury Analyzer. The side-by-side testing included standards for instrument calibration verifications, spiked samples and unspiked samples. The standards were traceable back to the National Institute of Standards and Technology (NIST). The side-by-side work included the analysis of Sludge Receipt and Adjustment Tank (SRAT) Receipt, SRAT Product, and Slurry Mix Evaporator (SME) samples. With the qualification of the Nippon Mercury/RA-3000 system in M-14, the DWPF lab will be able to perform a head to head comparison of a second Nippon Mercury/RA-3000 system once the system is installed. 


\section{TABLE OF CONTENTS}

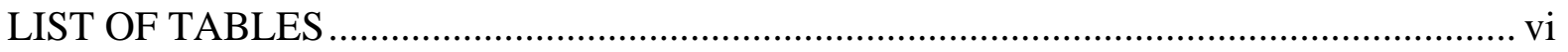

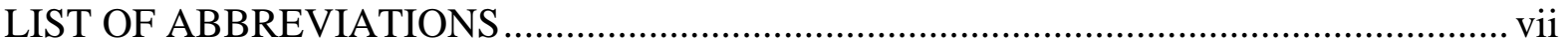

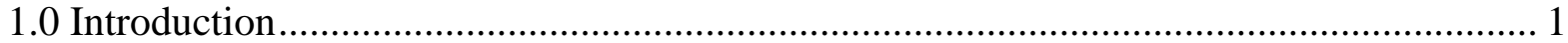

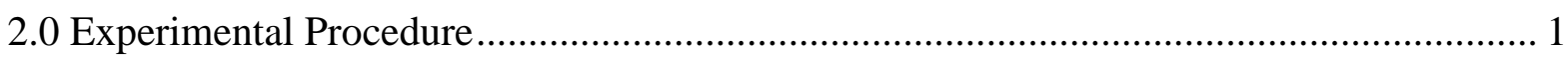

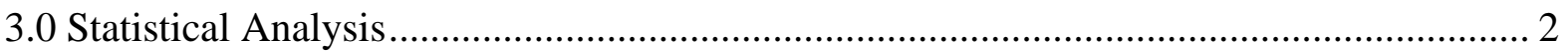

3.1 Comparisons of the Two Instruments Based Upon the Hg Measurements of Samples .. 2

3.2 Comparisons of the Two Instruments Based Upon the Hg Recovery Values of Samples

3.3 Comparisons of the Two Instruments Based Upon the Hg Recovery Values of the

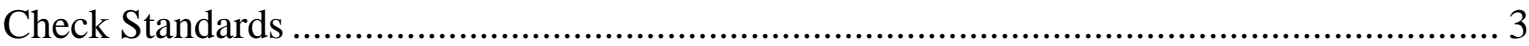

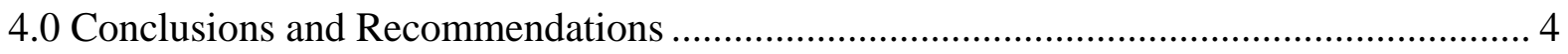

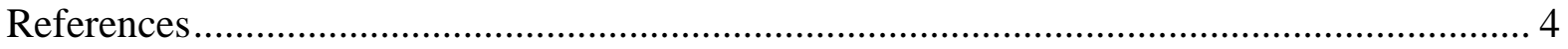


SRNL-STI-2010-00612

Revision 0

\section{LIST OF TABLES}

Table 1. Illustration of Mercury (Hg) Measurements for a Given SRAT Batch ................................... 2 


\section{LIST OF ABBREVIATIONS}

$\begin{array}{ll}\text { DWPF } & \text { Defense Waste Processing Facility } \\ \text { Hg } & \text { Mercury } \\ \text { HLW } & \text { High Level Waste } \\ \text { JMP } & \text { Statistical software package from SAS Institute, Inc. [3] } \\ \text { NIST } & \text { National Institute of Standards and Technology } \\ \text { pPm } & \text { Parts per million } \\ \text { SME } & \text { Slurry Mix Evaporator } \\ \text { SRAT } & \text { Slurry Receipt and Adjustment Tank } \\ \text { SRNL } & \text { Savannah River National Laboratory } \\ \text { TTR } & \text { Technical Task Request } \\ \text { TT\&QA } & \text { Task Technical and Quality Assurance }\end{array}$




\subsection{INTRODUCTION}

The Defense Waste Processing Facility (DWPF) analyzes receipt and product samples from the Sludge Receipt and Adjustment Tank (SRAT) to determine the mercury (Hg) concentration in the sludge slurry. The SRAT receipt is typically sampled and analyzed for the first ten SRAT batches of a new sludge batch to obtain an average $\mathrm{Hg}$ concentration. This average $\mathrm{Hg}$ concentration is then used to determine the amount of steam stripping required during the concentration/reflux step of the SRAT cycle to achieve a less than $0.6 \mathrm{wt} \% \mathrm{Hg}$ in the SRAT product solids. After processing is complete, the SRAT product is sampled and analyzed for mercury to ensure that the mercury concentration does not exceed the $0.45 \mathrm{wt} \%$ limit in the Slurry Mix Evaporator (SME).

The DWPF Laboratory utilizes Bacharach Analyzers to support these $\mathrm{Hg}$ analyses at this facility. These analyzers are more than 10 years old, and they are no longer supported by the manufacturer. Due to these difficulties, the Bacharach Analyzers are to be replaced by new Nippon Mercury/RA3000 systems. DWPF issued a Technical Task Request (TTR) [1] for the Savannah River National Laboratory (SRNL) to assist in the qualification of the new systems. SRNL prepared a task technical and quality assurance (TT\&QA) plan [2] that outlined the activities that are necessary and sufficient to meet the objectives of the TTR. In addition, TT\&QA plan also included a test plan that provided guidance to the DWPF Lab in collecting the data needed to qualify the new Nippon Mercury/RA3000 systems.

\subsection{Experimental Procedure}

The qualification of the Nippon Mercury/RA-3000 system installed in 221-S M-14 for use in the measurement of mercury for SRAT receipt and product samples will rely on side-by-side measurements that were conducted by the DWPF Lab. The side-by-side comparisons were performed for samples from SRAT batches and some limited samples of the SME product. In addition, during the processing of the SRAT batches (i.e., after the sampling of the SRAT Receipt but before the sampling of the SRAT Product), some intermediate samples were taken. These samples are labeled as "Conflux" samples.

Typically, four samples were taken from each batch of material for which the mercury content was measured. The samples were prepared for analysis: two samples "as-is" and two spiked with a mercury standard. The mercury concentrations of the two "as-is" samples were measured by the Bacharach Analyzer as done today. In addition, the same samples were measured by the Nippon Mercury/RA-3000 system. It should be noted that the Nippon instrument, which operates at lower Hg concentrations than the Bacharach, required an additional dilution before analysis. Sample identifiers were established and maintained so that the Bacharach and Nippon measurements for each sample may be paired appropriately. This is illustrated in Table 1, where the X's, Y's, A's and B's represent the measurements to be generated by DWPF Lab. Note that the $\mathrm{X}$ and $\mathrm{Y}$ values represent the mercury values in parts per million (ppm), the values of interest, from the "as-is" samples while the A and B values represent the percent (\%) recoveries of mercury $(\mathrm{Hg})$ for the spiked samples for the two instruments, respectively; \% $\mathrm{Hg}$ recovery is the determination of interest that the DWPF Lab performs for the spiked samples. 
Table 1. Illustration of Mercury (Hg) Measurements for a Given SRAT Batch

\begin{tabular}{|c|c|c|c|c|c|}
\hline $\begin{array}{c}\text { Sample } \\
\text { ID }\end{array}$ & Type & $\begin{array}{c}\text { Bacharach } \\
\mathrm{Hg}(\mathrm{ppm})\end{array}$ & $\begin{array}{c}\text { Nippon/RA-3000 } \\
\mathrm{Hg}(\mathrm{ppm})\end{array}$ & $\begin{array}{c}\text { Bacharach } \\
\text { \% Recovery }\end{array}$ & $\begin{array}{c}\text { Nippon/RA-3000 } \\
\text { \% Recovery }\end{array}$ \\
\hline Sample 1 & As-is & $\mathrm{X}_{1}$ & $\mathrm{Y}_{1}$ & Not Appropriate & Not Appropriate \\
\hline Sample 2 & As-is & $\mathrm{X}_{2}$ & $\mathrm{Y}_{2}$ & Not Appropriate & Not Appropriate \\
\hline Sample 3 & Spiked & Not Reported & Not Reported & $\mathrm{A}_{1}$ & $\mathrm{~B}_{1}$ \\
\hline Sample 4 & Spiked & Not Reported & Not Reported & $\mathrm{A}_{2}$ & $\mathrm{~B}_{2}$ \\
\hline
\end{tabular}

Following this plan led to the generation by the DWPF Lab of the mercury measurements provided in Table A1 in the Appendix for the "as-is" samples and of the percent recovery values in Table A2 in the Appendix. Table 2 presents the spike recovery data from the two spiked samples analyzed along with the "as-is" samples. The established spike recovery limits for the method are 65 - 135\%. While the spike recovery data show some variation, the recoveries are within the established range and are generally consistent between the instruments suggesting that spike recovery is not an instrument problem, but may reflect something inherent within the method. Recent mercury method work performed in SRNL and DWPF [3] concluded that "the current spike protocol for quality control does not appear to be effective. The spike failures do not correlate with the analyses of the unspiked samples for reasons that are still not known." Again, it is believed that the spike recovery problems are more of a method problem, rather than an instrument problem. Percent recoveries of check standards measured by the instruments are provided in Table A3 in the Appendix. The check standards were used in the block of measurements conducted by the DWPF Lab: a check standard early in the block (labeled as "first") and a check standard late in the block (labeled as "second"). The standards were traceable back to the National Institute of Standards and Technology (NIST).

The measurements in Tables A1 through A3 provide the basis for the analysis presented in this report. The two rows of Table A1 corresponding to measurements of SME Product samples are shaded to highlight the limited amount of data from this type of material. Due to the limited data and the fact that the mercury content of this material is not typically measured, these data are not included in the statistical analyses that follow. A row corresponding to a spiked sample of SRAT Product Batch 525 is shaded in Table A2 to indicate the unacceptable value (-48.4\%) generated by the Bacharach instrument. This row of data is not included in the analyses that follow.

\subsection{Statistical ANAL YSIS}

In this section, the statistical comparisons of the measurements generated by the two mercury instruments are presented. JMP Version 7.0.2 [4] was used to perform these analyses. Of primary interest are investigations into any relative bias between the two measurement systems and into a comparison of their precisions. Each of the three data tables is investigated in turn over the next three sections that follow to address the issues of concern.

\subsection{Comparisons of the Two Instruments Based Upon the Hg Measurements of Samples}

Exhibit A1 in the Appendix provides a plot of the Hg measurements of Table A1. The data are grouped by Type of Batch. The SME Product results are shown in this plot. While they suggest no problem in the performance of the two instruments, due to the limited amount of data for the type of material, these measurements are not included in the statistical analyses that follow. The groupings of the other measurement data provide the basis for the evaluation of the two instruments using a "paired-sample" analysis. 
Exhibit A2 in the Appendix provides this comparison for the measurements from Conflux samples. Included in this exhibit is a plot of the Nippon measurements versus the Bacharach measurements along with a fitted model that assesses the relative bias between the measurements of the two instruments. That bias would be considered statistically significant if the "Prob $>|t|$ " value in the "Parameter Estimates" table is 0.05 or smaller. For this analysis, the value is 0.0606 , so it would not be considered significant at the 5\% level. Also included in this exhibit are the results of a direct "Matched Pairs" analysis from JMP. That analysis indicates the same "Prob>|t|" value of 0.0606, but it also provides a 95\% confidence interval for the average difference between the two instruments for this set of measurements. That interval is given by the two entries: Upper95\% and Lower95\%. These values yield the interval -204.22 to 5.26191, which indicates that the relative bias in ppm between the two instruments for these Conflux measurements is bounded by 204.22 ppm with at least 95\% confidence.

Exhibits A3 and A4 in the Appendix provide similar results for the measurements of the SRAT Product and SRAT Receipt samples, respectively. There is no indication of a statistically significant bias (at the 5\% significance level) between the two instruments for either of these two sets of measurements. For the SRAT Product samples, the relative bias between the two instruments is bounded by 68 ppm while the bias is bounded by 185.4 ppm for the SRAT Receipt samples.

One the aspect of the results from Exhibits A2 through A4 that is notable is the pattern of scatter around the fitted line for Exhibit A2. The smallest Hg measurements of this plot fall above this line while the two largest Hg values fall below this line. This indicates that for the Conflux samples, the Nippon yielded larger values than the Bacharach for lower $\mathrm{Hg}$ concentrations and smaller measurements than the Bacharach at higher Hg concentrations. This pattern was not evident in the SRAT Product and SRAT Receipt samples.

\subsection{Comparisons of the Two Instruments Based Upon the Hg Recovery Values of Samples}

Exhibits A5, A6, and A7 in the Appendix provide analyses of the percent recovery values of the Conflux, SRAT Product, and SRAT Receipt samples, respectively, that are similar to the analyses of the $\mathrm{Hg}$ measurements presented in the previous section. Based upon the results shown in these exhibits, the only indication of a statistically significant (at the $5 \%$ level) bias between the two instruments is for the SRAT Product sample measurements. Even so, the bias for this difference is bounded by $12.6 \%$ with at least $95 \%$ confidence. While not statistically significant at the $5 \%$ level, the bias between the two instruments is bounded by $20.6 \%$ for the Conflux samples and by $16.7 \%$ for the SRAT Receipt samples.

\subsection{Comparisons of the Two Instruments Based Upon the Hg Recovery Values of the Check Standards}

Exhibit A8 in the Appendix provides a plot of and some summary statistics for the percent recovery values of the check standards that are presented in Table A3. The check standard measurements are grouped by instrument and by their place in sequence of measurements (the first is labeled as \% Rec and the second as \% Rec 2). Box plots and 95\% confidence interval diamonds are provided for each set of measurements. Summary statistics (i.e., the sample mean, the sample standard deviation, the standard error of the mean (Std Err Mean), the lower and upper limits of the confidence interval, the minimum value, the maximum value, and the number of observations (Obs) in the group are also provided as part of the exhibit. A closer look at these summary statistics is provided in the following discussion. 
Exhibit A9 in the Appendix provides a comparison between the measurements of the first check standard for the two instruments. Included in this exhibit, is a series of statistical tests for equality of variances for these measurements between the two instruments. Relying on the results of Levene's test indicates that there is no indication of a statistically significant (at the $5 \%$ level) difference in the variances of the measurements from the two instruments. The t-test for equality of means also shows no indication of a statistically significant (at the 5\% level) difference between the two instruments. The 95\% confidence interval indicates that the difference or bias between the two instruments is bounded by $4.2 \%$.

Exhibit A10 in the Appendix provides a similar comparison between the measurements of the second check standard for the two instruments. For these data, Levene's test indicates that there is indication a statistically significant (at the 5\% level) difference in the variances of the measurements from the two instruments with the measurements from the Nippon yielding a smaller variance. While the t-test for equality of means shows a statistically significant (at the $5 \%$ level) difference between the two instruments. The 95\% confidence interval indicates that the difference or bias between the two instruments is bounded by $7.4 \%$ with the Nippon yielding, on average, a smaller \% recovery value.

\subsection{CONCLUSIONS AND RECOMMENDATIONS}

Based upon the results presented in this report, it is recommended that the Nippon Mercury/RA-3000 system installed in 221-S M-14 has been qualified for use. The qualification was a side-by-side comparison of the Nippon Mercury/RA-3000 system with the currently used Bacharach Mercury Analyzer. The side-by-side testing included standards for instrument calibration verifications, spiked samples and unspiked samples. The standards were traceable back to NIST. The side-by-side work included the analysis of SRAT Receipt, SRAT Product, and SME samples. With the qualification of the Nippon Mercury/RA-3000 system in M-14, the DWPF lab will be able to perform a head to head comparison of a second Nippon Mercury/RA-3000 system once the system is installed.

\section{REFERENCES}

[1] Brown, AY, “Technical Task Request: Develop Qualification Test Plan and Result Analysis for DWPF Lab New Mercury Analyzer RA-3000,” HLW/DWPF/TTR-2009-0020, Revision 0, April, 2009.

[2] Edwards, TB, “Task Technical \& QA Plan: Develop a Qualification Test Plan and Provide a Results Analysis for the New Mercury Analyzer RA-3000 Systems at DWPF Lab,” SRNLRP-2009-00971, Revision 0, July, 2009.

[3] Coleman, CJ, et al., "Evaluation of Sample Preparation Methods for Mercury Determinations in DWPF Sludge,” SRNS-STI-2009-00315, Revision 0, August, 2009.

[4] JMP Version 7.0.2, SAS Institute, Inc., Cary NC, 1989-2007. 


\section{Appendix: Tables and Exhibits}

\section{Table A1. Mercury Measurements (ppm) of Samples by Instrument}

\begin{tabular}{|c|c|c|c|}
\hline Type of Batch & Batch & Bacharach Analyzer Hg (ppm) & Nippon/RA-3000 Hg (ppm) \\
\hline SRAT Receipt & 524 & 2562.7 & 2462.7 \\
\hline SRAT Receipt & 524 & 2673.4 & 2534.3 \\
\hline SRAT Receipt & 525 & 2419.7 & 2443.2 \\
\hline SRAT Receipt & 525 & 2360.7 & 2312.2 \\
\hline SRAT Receipt & 526 & 2235.1 & 2247 \\
\hline SRAT Receipt & 526 & 2344 & 2303.4 \\
\hline SRAT Receipt & 527 & 2070 & 2059.5 \\
\hline SRAT Receipt & 527 & 1883.2 & 1898.5 \\
\hline SRAT Product & 524 & 762.3 & 715 \\
\hline SRAT Product & 524 & 694.4 & 722.6 \\
\hline SRAT Product & 525 & 1415.3 & 1361 \\
\hline SRAT Product & 525 & 1438.7 & 1366.4 \\
\hline SRAT Product & 526 & 175.5 & 172.9 \\
\hline SRAT Product & 526 & 173.3 & 170.5 \\
\hline SRAT Product & 527 & 421.4 & 641.3 \\
\hline SRAT Product & 527 & 436.6 & 617.5 \\
\hline SRAT Product & 534 & 1488.2 & 1403.4 \\
\hline SRAT Receipt & 535 & 3771.1 & 4150.8 \\
\hline Conflux* & $535 a$ & 2714.3 & 2380.3 \\
\hline SRAT Product & 535 & 891.7 & 895.3 \\
\hline SRAT Receipt & 536 & 3442.1 & 3343.8 \\
\hline Conflux* & $536 a$ & 3139.1 & 2747.0 \\
\hline Conflux* & $536 \mathrm{~b}$ & 2607.5 & 2727.0 \\
\hline Conflux* & $536 c$ & 2306.7 & 2121.2 \\
\hline Conflux* & $536 \mathrm{~d}$ & 1286.1 & 1254.0 \\
\hline Conflux* & $536 \mathrm{e}$ & 1036.1 & 1076.9 \\
\hline SRAT Product & 536 & 770.0 & 723.5 \\
\hline SRAT Product & $536 * *$ & 771.0 & 628.0 \\
\hline SME Product & 535 & 518.7 & 485.7 \\
\hline SRAT Product & 534 & 1491.5 & 1369.0 \\
\hline SRAT Receipt & 535 & 3918.7 & 3327.1 \\
\hline Conflux* & $535 a$ & 2707.3 & 2546.7 \\
\hline SRAT Product & 535 & 881.6 & 837.9 \\
\hline SRAT Receipt & 536 & 3350.1 & 3365.5 \\
\hline Conflux* & $536 a$ & 3152.7 & 2904.6 \\
\hline Conflux* & $536 \mathrm{~b}$ & 2624.7 & 2523.7 \\
\hline Conflux* & $536 c$ & 2355.9 & 2377.7 \\
\hline Conflux* & $536 \mathrm{~d}$ & 1307.6 & 1349.9 \\
\hline Conflux* & $536 \mathrm{e}$ & 1018.7 & 1054.1 \\
\hline SRAT Product & 536 & 766.5 & 754.3 \\
\hline SRAT Product & $536^{* *}$ & & \\
\hline SME Product & 535 & 499.9 & 529.9 \\
\hline
\end{tabular}


SRNL-STI-2010-00612

Revision 0

Table A2. Percent Recoveries of Spiked Samples by Instrument

\begin{tabular}{|c|c|c|c|}
\hline Type of Batch & Batch & Bacharach \% Recovery & Nippon/RA-3000 \% Recovery \\
\hline SRAT Receipt & 524 & 62.2 & 60.9 \\
\hline SRAT Receipt & 524 & 100.4 & 99.7 \\
\hline SRAT Receipt & 525 & 109.6 & 105 \\
\hline SRAT Receipt & 525 & 46.2 & 81.4 \\
\hline SRAT Receipt & 526 & 98.3 & 94.6 \\
\hline SRAT Receipt & 526 & 108 & 104.8 \\
\hline SRAT Receipt & 527 & 75.2 & 99.8 \\
\hline SRAT Receipt & 527 & 77 & 86.9 \\
\hline SRAT Product & 524 & 80.8 & 98.6 \\
\hline SRAT Product & 524 & 84.1 & 110.7 \\
\hline SRAT Product & 525 & -48.4 & 107.4 \\
\hline SRAT Product & 525 & 81.9 & 83 \\
\hline SRAT Product & 526 & 66.1 & 70.8 \\
\hline SRAT Product & 526 & 70 & 66.4 \\
\hline SRAT Product & 527 & 52 & 73.6 \\
\hline SRAT Product & 527 & 65.6 & 68.4 \\
\hline SRAT Product & 534 & 111.8 & 103.0 \\
\hline SRAT Receipt & 535 & 69.5 & 75.2 \\
\hline Conflux* & $535 a$ & 36.7 & 76.0 \\
\hline SRAT Product & 535 & 80.1 & 82.7 \\
\hline SRAT Receipt & 536 & 66.1 & 79.1 \\
\hline Conflux* & 536a & 78.3 & 102.0 \\
\hline Conflux* & $536 b$ & 72.5 & 64.2 \\
\hline Conflux* & $536 c$ & 80.3 & 91.7 \\
\hline Conflux* & $536 d$ & 59.5 & 64.2 \\
\hline Conflux* & $536 \mathrm{e}$ & 64.0 & 58.7 \\
\hline SRAT Product & 536 & 21.6 & 23.3 \\
\hline SRAT Product & $536 * *$ & 18.4 & 11.1 \\
\hline SME Product & 535 & 89.1 & 101.6 \\
\hline SRAT Product & 534 & 119.8 & 116.9 \\
\hline SRAT Receipt & 535 & 71.6 & 97.3 \\
\hline Conflux* & $535 a$ & 77.4 & 92.6 \\
\hline SRAT Product & 535 & 68.0 & 81.7 \\
\hline SRAT Receipt & 536 & 102.4 & 92.5 \\
\hline Conflux* & 536a & 38.2 & 80.2 \\
\hline Conflux* & $536 b$ & 112.6 & 108.3 \\
\hline Conflux* & $536 c$ & 81.7 & 87.2 \\
\hline Conflux* & $536 \mathrm{~d}$ & 61.6 & 61.2 \\
\hline Conflux* & $536 \mathrm{e}$ & 72.3 & 57.7 \\
\hline SRAT Product & 536 & 41.2 & 47.3 \\
\hline SRAT Product & $536 * *$ & 22.6 & 43.8 \\
\hline SME Product & 535 & 87.3 & 100.3 \\
\hline
\end{tabular}


Table A3. Percent Recoveries of Check Standards by Instrument

\begin{tabular}{|c|c|c|c|}
\hline Instrument/Ck Std & Instrument & Sequence of Ck Std & \% Recovery \\
\hline Bacharach/first & Bacharach & Check Std Bach \% Rec & 95.5 \\
\hline Bacharach/first & Bacharach & Check Std Bach \% Rec & 96.7 \\
\hline Bacharach/first & Bacharach & Check Std Bach \% Rec & 106.4 \\
\hline Bacharach/first & Bacharach & Check Std Bach \% Rec & 94.0 \\
\hline Bacharach/first & Bacharach & Check Std Bach \% Rec & 97.6 \\
\hline Bacharach/first & Bacharach & Check Std Bach \% Rec & 95.0 \\
\hline Bacharach/first & Bacharach & Check Std Bach \% Rec & 100.3 \\
\hline Bacharach/first & Bacharach & Check Std Bach \% Rec & 99.2 \\
\hline Bacharach/first & Bacharach & Check Std Bach \% Rec & 94.9 \\
\hline Bacharach/first & Bacharach & Check Std Bach \% Rec & 97.6 \\
\hline Bacharach/first & Bacharach & Check Std Bach \% Rec & 99.1 \\
\hline Bacharach/first & Bacharach & Check Std Bach \% Rec & 97.4 \\
\hline Bacharach/first & Bacharach & Check Std Bach \% Rec & 91.7 \\
\hline Bacharach/second & Bacharach & Check Std Bach \% Rec 2 & 95.9 \\
\hline Bacharach/second & Bacharach & Check Std Bach \% Rec 2 & 105.9 \\
\hline Bacharach/second & Bacharach & Check Std Bach \% Rec 2 & 103.8 \\
\hline Bacharach/second & Bacharach & Check Std Bach \% Rec 2 & 104.4 \\
\hline Bacharach/second & Bacharach & Check Std Bach \% Rec 2 & 92.8 \\
\hline Bacharach/second & Bacharach & Check Std Bach \% Rec 2 & 97.0 \\
\hline Bacharach/second & Bacharach & Check Std Bach \% Rec 2 & 98.0 \\
\hline Bacharach/second & Bacharach & Check Std Bach \% Rec 2 & 96.8 \\
\hline Bacharach/second & Bacharach & Check Std Bach \% Rec 2 & 101.4 \\
\hline Bacharach/second & Bacharach & Check Std Bach \% Rec 2 & 96.3 \\
\hline Bacharach/second & Bacharach & Check Std Bach \% Rec 2 & 102.8 \\
\hline Bacharach/second & Bacharach & Check Std Bach \% Rec 2 & 97.7 \\
\hline Bacharach/second & Bacharach & Check Std Bach \% Rec 2 & 95.7 \\
\hline Nippon/first & Nippon & Check Std Nippon \% Rec & 97.4 \\
\hline Nippon/first & Nippon & Check Std Nippon \% Rec & 90.9 \\
\hline Nippon/first & Nippon & Check Std Nippon \% Rec & 99.1 \\
\hline Nippon/first & Nippon & Check Std Nippon \% Rec & 98.8 \\
\hline Nippon/first & Nippon & Check Std Nippon \% Rec & 96.3 \\
\hline Nippon/first & Nippon & Check Std Nippon \% Rec & 98.9 \\
\hline Nippon/first & Nippon & Check Std Nippon \% Rec & 96.4 \\
\hline Nippon/first & Nippon & Check Std Nippon \% Rec & 94.2 \\
\hline Nippon/first & Nippon & Check Std Nippon \% Rec & 95.1 \\
\hline Nippon/first & Nippon & Check Std Nippon \% Rec & 98.7 \\
\hline Nippon/first & Nippon & Check Std Nippon \% Rec & 93.4 \\
\hline Nippon/first & Nippon & Check Std Nippon \% Rec & 93.1 \\
\hline Nippon/first & Nippon & Check Std Nippon \% Rec & 92.5 \\
\hline Nippon/second & Nippon & Check Std Nippon \% Rec 2 & 96.2 \\
\hline Nippon/second & Nippon & Check Std Nippon \% Rec 2 & 100.4 \\
\hline Nippon/second & Nippon & Check Std Nippon \% Rec 2 & 91.6 \\
\hline Nippon/second & Nippon & Check Std Nippon \% Rec 2 & 99.1 \\
\hline Nippon/second & Nippon & Check Std Nippon \% Rec 2 & 92.3 \\
\hline Nippon/second & Nippon & Check Std Nippon \% Rec 2 & 93.1 \\
\hline Nippon/second & Nippon & Check Std Nippon \% Rec 2 & 92.2 \\
\hline Nippon/second & Nippon & Check Std Nippon \% Rec 2 & 92.1 \\
\hline Nippon/second & Nippon & Check Std Nippon \% Rec 2 & 94.4 \\
\hline Nippon/second & Nippon & Check Std Nippon \% Rec 2 & 94.7 \\
\hline Nippon/second & Nippon & Check Std Nippon \% Rec 2 & 94.7 \\
\hline Nippon/second & Nippon & Check Std Nippon \% Rec 2 & 94.4 \\
\hline Nippon/second & Nippon & Check Std Nippon \% Rec 2 & 93.1 \\
\hline
\end{tabular}




\section{Exhibit A1. Variability Chart for Hg (ppm) Measurements}

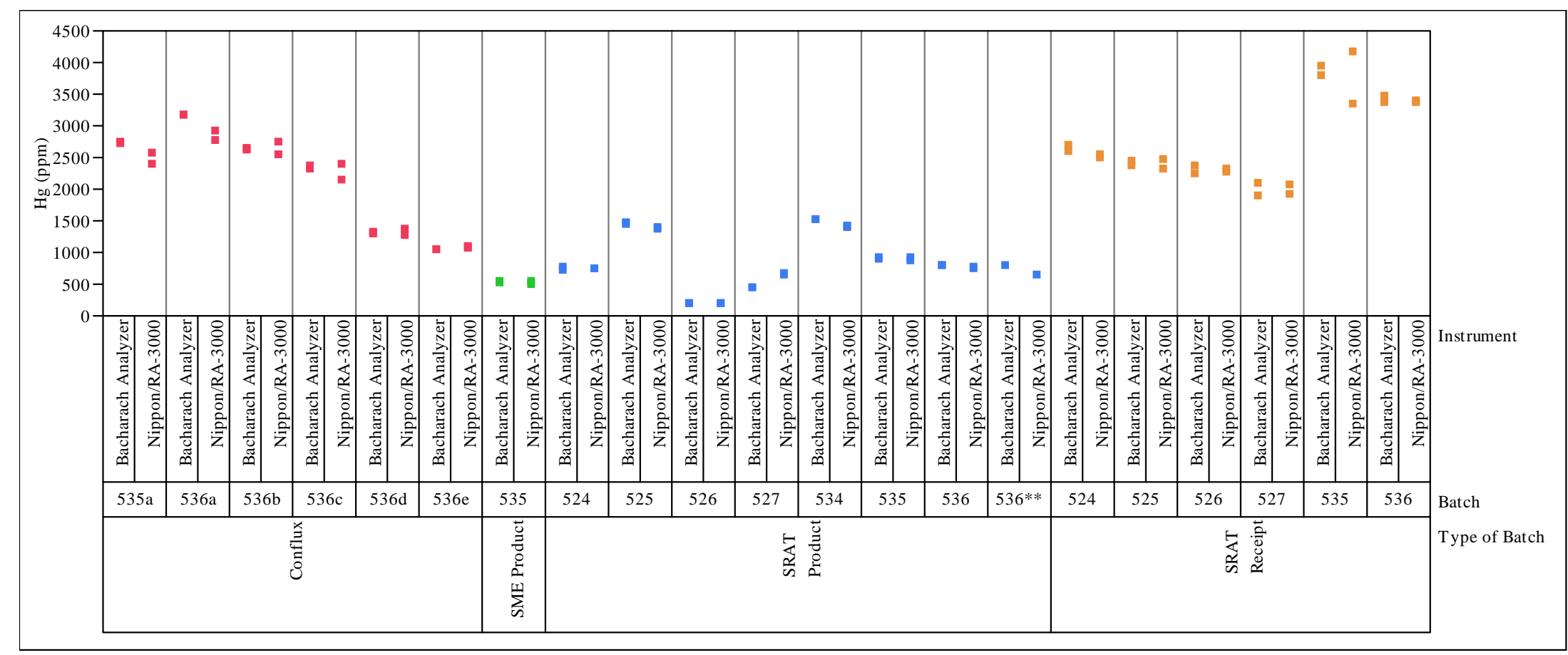




\section{Exhibit A2. Paired Comparison of Hg Measurements for Conflux Samples}

Bivariate Fit of Nippon/RA-3000 Hg (ppm) By Bacharach Analyzer Hg (ppm) Type of Batch=Conflux

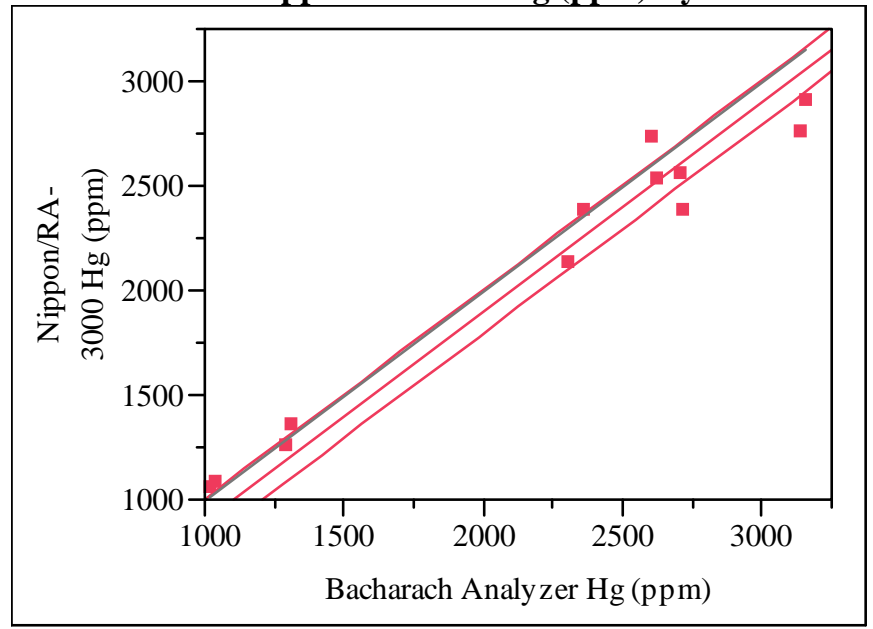

\section{$\equiv$ Linear Fit}

Linear Fit

Nippon/RA-3000 Hg (ppm) = -99.477 + 1*Bacharach Analyzer Hg (ppm)

\section{Summary of Fit}

RSquare

RSquare Adj

Root Mean Square Error $\quad 164.8472$

Mean of Response 2088.591

Observations (or Sum Wgts) 12

$\begin{array}{lrrrr}\begin{array}{l}\text { Analysis of Variance } \\ \text { Source }\end{array} & \text { DF } & \text { Sum of Squares } & \text { Mean Square } & \text { F Ratio } \\ \text { Model } & 0 & \text {. } & 0.0 & \text {. } \\ \text { Error } & 11 & 298920.55 & 27174.6 & \text { Prob }>\text { F } \\ \text { C. Total } & 11 & \text {. } & & \end{array}$

\section{Parameter Estimates}

Term

Intercept

Bacharach Analyzer Hg (ppm) Constrained

Estimate Std Error t Ratio Prob $>|\mathbf{t}|$ $\begin{array}{llll}-99.477 & 47.58728 & -2.09 & 0.0606\end{array}$

\section{Matched Pairs Type of Batch=Conflux*}

Difference: Nippon/RA-3000 Hg (ppm)-Bacharach Analyzer Hg (ppm)

Nippon/RA-3000 Hg (ppm)
Bacharach Analyzer Hg (ppm)
Mean Difference
Std Error
Upper95\%
Lower95\%
N
Correlation

$\begin{array}{rlr}2088.59 & \text { t-Ratio } & -2.09041 \\ 2188.07 & \text { DF } & 11 \\ -99.477 & \text { Prob }>|t| & 0.0606 \\ 47.5873 & \text { Prob }>\text { t } & 0.9697 \\ 5.26191 & \text { Prob }<\mathrm{t} & 0.0303 \\ -204.22 & & \\ 12 & & \\ 0.98482 & & \end{array}$




\section{Exhibit A3. Paired Comparison of Hg Measurements for SRAT Product Samples}

Bivariate Fit of Nippon/RA-3000 Hg (ppm) By Bacharach Analyzer Hg (ppm) Type of Batch=SRAT Product

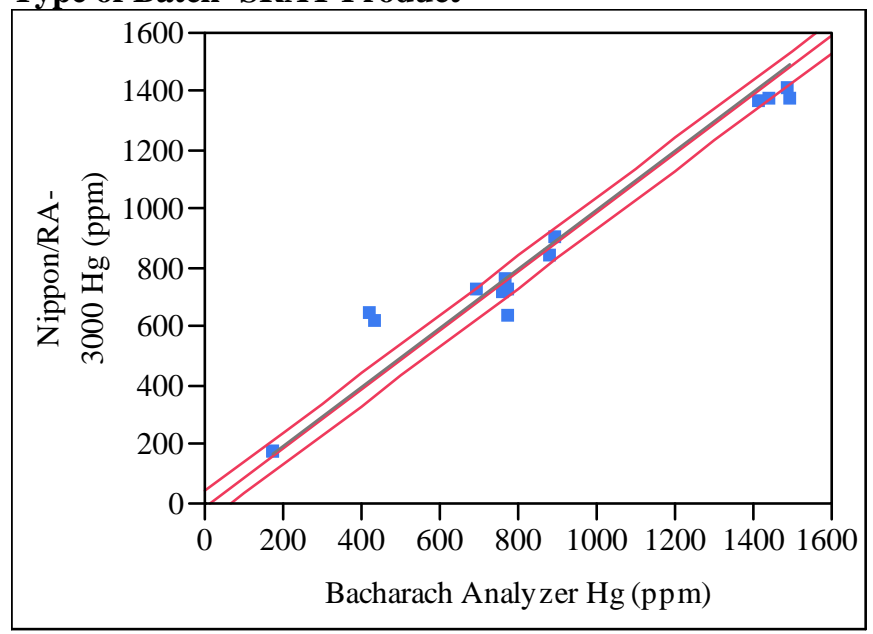

$\bar{\equiv}$ Linear Fit

Linear Fit

Nippon/RA-3000 Hg $(\mathrm{ppm})=-13.29064+1 *$ Bacharach Analyzer Hg (ppm)

Summary of Fit

RSquare

RSquare Adj

Root Mean Square Error $\quad 98.75381$

Mean of Response $\quad 825.25$

Observations (or Sum Wgts) 15

Analysis of Variance

Source DF Sum of Squares Mean Square F Ratio

Model $0 \quad 0.00$

$\begin{array}{llll}\text { Error } & 14 & 136532.42 & 9752.32 \text { Prob }>\text { F }\end{array}$

C. Total 14

Parameter Estimates

Term

Intercept

Estimate Std Error t Ratio Prob $>|\mathbf{t}|$

Bacharach Analyzer Hg (ppm) Constrained

$\begin{array}{llll}-13.29064 & 25.49813 & -0.52 & 0.6103\end{array}$

Matched Pairs Type of Batch=SRAT Product

Difference: Nippon/RA-3000 Hg (ppm)-Bacharach Analyzer Hg (ppm)

Nippon/RA-3000 Hg (ppm)

Bacharach Analyzer Hg (ppm)

Mean Difference

Std Error

Upper95\%

Lower95\%

$\mathrm{N}$

Correlation
825.25

838.541

$-13.291$

25.4981

41.3974

$-67.979$

15

0.97942

$\begin{array}{lr}\text { t-Ratio } & -0.52124 \\ \text { DF } & 14 \\ \text { Prob }>|t| & 0.6103 \\ \text { Prob }>\text { t } & 0.6948 \\ \text { Prob }<\text { t } & 0.3052\end{array}$




\section{Exhibit A4. Paired Comparison of Hg Measurements for SRAT Receipt Samples}

Bivariate Fit of Nippon/RA-3000 Hg (ppm) By Bacharach Analyzer Hg (ppm) Type of Batch=SRAT Receipt

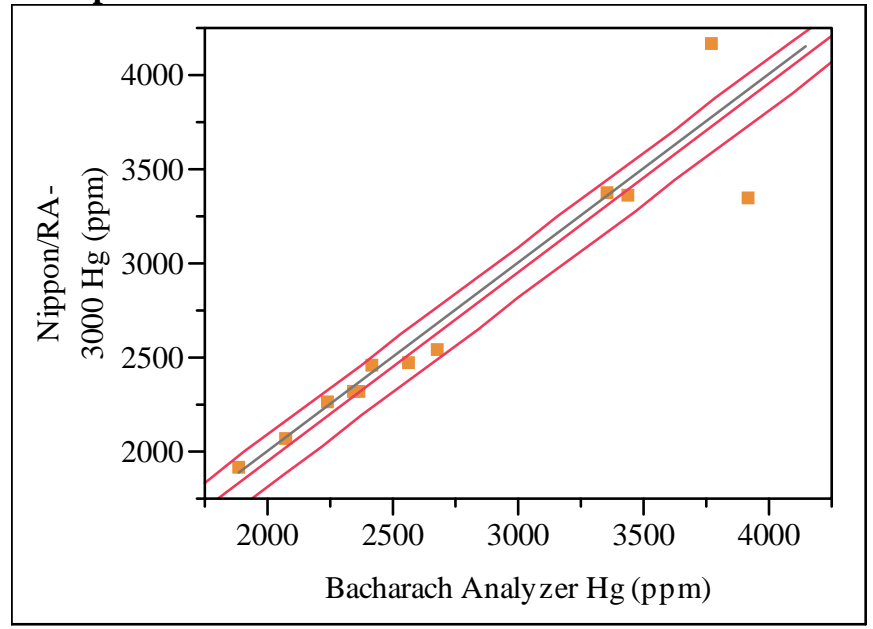

Linear Fit

Linear Fit

Nippon/RA-3000 Hg (ppm) = -48.57432 + 1*Bacharach Analyzer Hg (ppm)

Summary of Fit

RSquare

RSquare Adj

Root Mean Square Error $\quad 215.3453$

Mean of Response 2703.995

Observations (or Sum Wgts) 12

Analysis of Variance

Source DF Sum of Squares Mean Square F Ratio

Model 0

Error 11

510109.49

0.0

C. Total 11

Parameter Estimates

Term

Estimate Std Error t Ratio Prob $>|\mathbf{t}|$

Intercept $-48.5743262 .16483$

$\begin{array}{ll}-0.78 & 0.4511\end{array}$

Bacharach Analyzer Hg (ppm) Constrained

Matched Pairs Type of Batch=SRAT Receipt

Difference: Nippon/RA-3000 Hg (ppm)-Bacharach Analyzer Hg (ppm)

Nippon/RA-3000 Hg (ppm)

Bacharach Analyzer Hg (ppm)

Mean Difference

Std Error

Upper95\%

Lower95\%

$\mathrm{N}$

Correlation

$\begin{array}{rlr}2703.99 & \text { t-Ratio } & -0.78138 \\ 2752.57 & \text { DF } & 11 \\ -48.574 & \text { Prob }>|t| & 0.4511 \\ 62.1648 & \text { Prob }>\text { t } & 0.7745 \\ 88.2495 & \text { Prob }<\text { t } & 0.2255 \\ -185.4 & & \\ 12 & & \\ 0.95037 & & \end{array}$


SRNL-STI-2010-00612

Revision 0

\section{Exhibit A5. Paired Comparison of \% Recovery Values for the Conflux Samples}

\section{Bivariate Fit of Nippon/RA-3000 \% Recovery By Bacharach \% Recovery Type of Batch=Conflux}

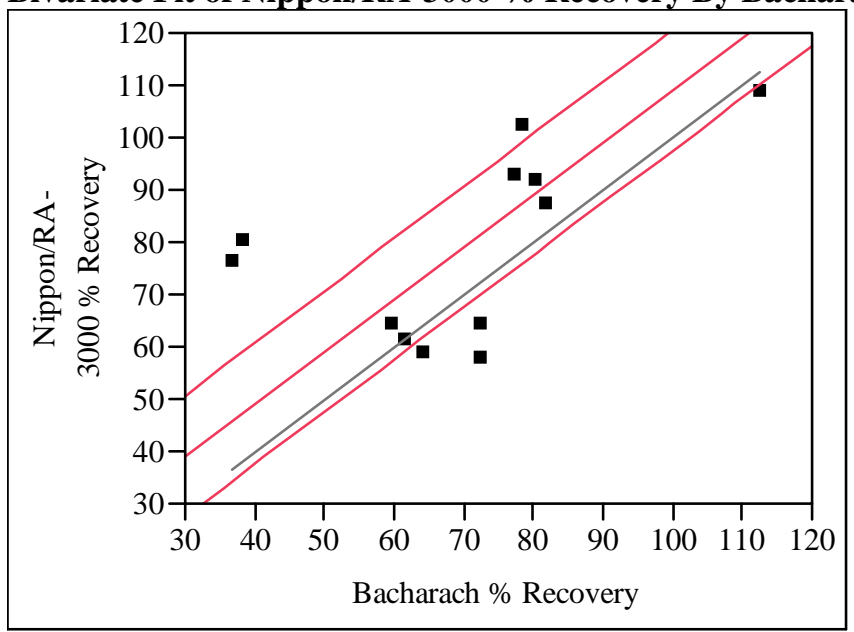

Linear Fit

Linear Fit

Nippon/RA-3000 \% Recovery $=9.0855966+1 *$ Bacharach \% Recovery

\section{Summary of Fit}

RSquare

RSquare Adj

Root Mean Square Error $\quad 18.16991$

Mean of Response 78.67035

Observations (or Sum Wgts) 12

Analysis of Variance

Source DF Sum of Squares Mean Square F Ratio

Model 0

0.000

Error 11

3631.6018

330.146 Prob $>$ F

C. Total 11

Parameter Estimates

Term

Intercept

Bacharach \% Recovery Constrained
Estimate Std Error t Ratio Prob $>|\mathbf{t}|$ $\begin{array}{llll}9.0855966 & 5.245201 & 1.73 & 0.1112\end{array}$

\section{Matched Pairs Type of Batch=Conflux}

Difference: Nippon/RA-3000 \% Recovery-Bacharach \% Recovery

Nippon/RA-3000 \% Recovery

Bacharach \% Recovery

Mean Difference

Std Error

Upper95\%

Lower95\%

$\mathrm{N}$

Correlation
78.6703

69.5848

9.0856

5.2452

20.6302

$-2.459$

12

0.54908

$\begin{array}{lr}\text { t-Ratio } & 1.732173 \\ \text { DF } & 11 \\ \text { Prob }>|t| & 0.1112 \\ \text { Prob }>\text { t } & 0.0556 \\ \text { Prob }<\mathrm{t} & 0.9444\end{array}$


SRNL-STI-2010-00612

Revision 0

\section{Exhibit A6. Paired Comparison of \% Recovery Values for the SRAT Product Samples}

Bivariate Fit of Nippon/RA-3000 \% Recovery By Bacharach \% Recovery Type of Batch=SRAT Product

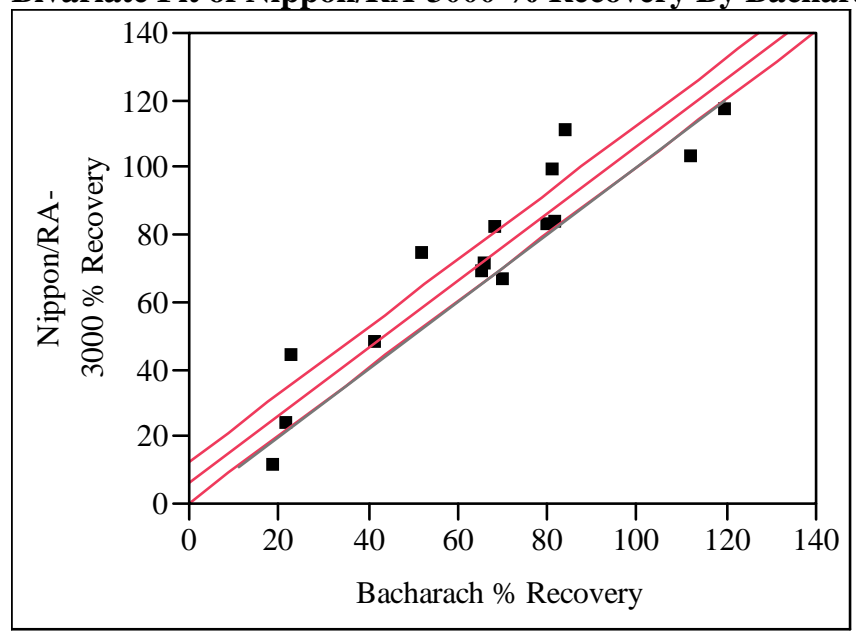

Linear Fit

Linear Fit

Nippon/RA-3000 \% Recovery $=6.4778938+1 *$ Bacharach \% Recovery

Summary of Fit

RSquare

RSquare Adj

Root Mean Square Error $\quad 11.10362$

Mean of Response 72.08514

Observations (or Sum Wgts) 15

Analysis of Variance

Source DF Sum of Squares Mean Square F Ratio

Model 0

0.000

Error $14 \quad 1726.0644 \quad 123.290$ Prob $>$ F

C. Total 14

Parameter Estimates

Term

Intercept

Estimate Std Error t Ratio Prob $>|\mathbf{t}|$

Bacharach \% Recovery Constrained $6.4778938 \quad 2.866942$

$2.26 \quad 0.0403$

Matched Pairs Type of Batch=SRAT Product

Difference: Nippon/RA-3000 \% Recovery-Bacharach \% Recovery

Nippon/RA-3000 \% Recovery

Bacharach \% Recovery

Mean Difference

Std Error

Upper95\%

Lower95\%

$\mathrm{N}$

72.0851

65.6072

6.47789

2.86694

12.6269

0.32892

Correlation

$\begin{array}{lr}\text { t-Ratio } & 2.259514 \\ \text { DF } & 14 \\ \text { Prob }>|t| & 0.0403 \\ \text { Prob }>\text { t } & 0.0202 \\ \text { Prob }<\mathrm{t} & 0.9798\end{array}$

15

0.9336 
SRNL-STI-2010-00612

Revision 0

\section{Exhibit A7. Paired Comparison of \% Recovery Values for the SRAT Receipt Samples}

Bivariate Fit of Nippon/RA-3000 \% Recovery By Bacharach \% Recovery Type of Batch=SRAT Receipt

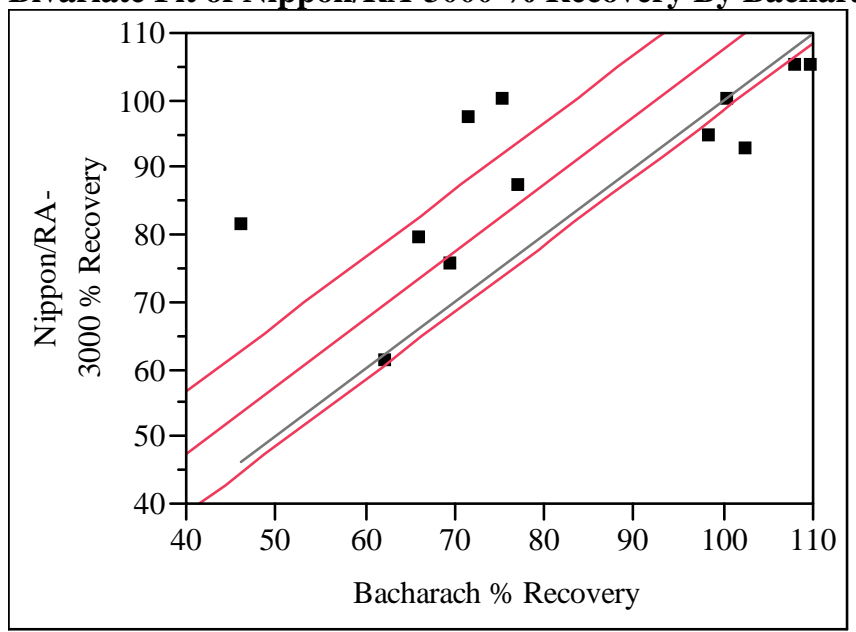

Linear Fit

Linear Fit

Nippon/RA-3000 \% Recovery $=7.5645302+1 *$ Bacharach \% Recovery

Summary of Fit

RSquare

RSquare Adj

Root Mean Square Error $\quad 14.34575$

Mean of Response 89.77153

Observations (or Sum Wgts) 12

Analysis of Variance

Source DF Sum of Squares Mean Square F Ratio

Model 0

0.000

Error 11

2263.8068

205.801 Prob $>$ F

C. Total 11

Parameter Estimates

Term

Estimate Std Error t Ratio Prob $>|\mathbf{t}|$

Intercept $7.5645302 \quad 4.141262$

1.830 .0950

Bacharach \% Recovery Constrained

Matched Pairs Type of Batch=SRAT Receipt

Difference: Nippon/RA-3000 \% Recovery-Bacharach \% Recovery

Nippon/RA-3000 \% Recovery

89.7715

82.207

t-Ratio

DF

Mean Difference

7.56453

Std Error

Upper95\%

Lower95\%

4.14126

16.6794

Prob $>|t|$

Prob $>\mathrm{t}$

Prob $<\mathrm{t}$

$-1.5503$

$\mathrm{N}$

12

Correlation

0.72557 
SRNL-STI-2010-00612

Revision 0

Exhibit A8. Evaluation of the \% Recovery Values for the Check Standards

Variability Chart for \% Recovery

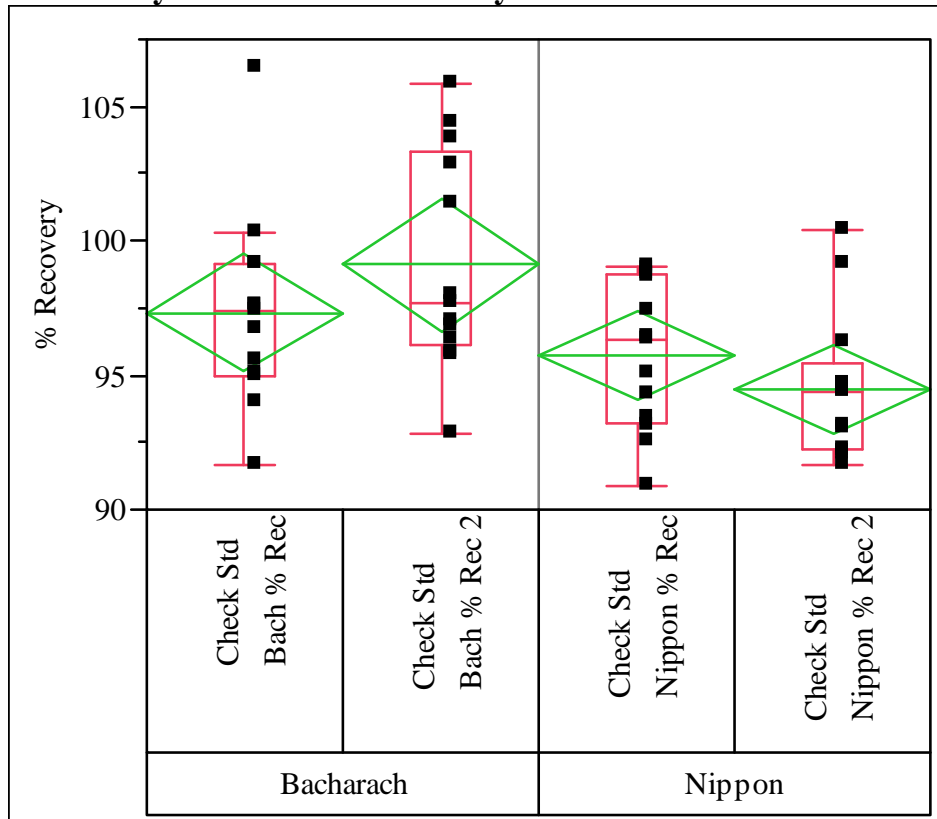

Sequence of Ck Std within Instrument

Variability Summary for \% Recovery

\begin{tabular}{|c|c|c|c|c|c|c|c|}
\hline Mean & Std Dev & $\begin{array}{r}\text { Std Err } \\
\text { Mean }\end{array}$ & $\begin{array}{r}\text { Lower } \\
95 \%\end{array}$ & $\begin{array}{r}\text { Upper } \\
95 \%\end{array}$ & Minimum & Maximum & Obs \\
\hline 98.22066 & 3.866269 & 0.758238 & 96.65904 & 99.78228 & 91.65 & 106.416 & 26 \\
\hline 95.11058 & 2.756131 & 0.540522 & 93.99735 & 96.2238 & 90.87 & 100.355 & 26 \\
\hline 97.33871 & 3.608543 & 1.00083 & 95.15809 & 99.51933 & 91.65 & 106.416 & 13 \\
\hline 99.10262 & 4.053989 & 1.124374 & 96.65281 & 101.5524 & 92.8 & 105.854 & 13 \\
\hline 95.75 & 2.763416 & 0.766434 & 94.08008 & 97.41992 & 90.87 & 99.05 & 13 \\
\hline 94.47115 & 2.702444 & 0.749523 & 92.83808 & 96.10422 & 91.635 & 100.355 & 13 \\
\hline
\end{tabular}

Instrument[Bacharach]

Instrument[Nippon]

Instrument[Bacharach]

Sequence of Ck Std[Check Std Bach \% Rec]

Instrument[Bacharach]

Sequence of Ck Std[Check Std Bach \% Rec 2]

Instrument[Nippon]

Sequence of Ck Std[Check Std Nippon \% Rec]

Instrument[Nippon]

Sequence of Ck Std[Check Std Nippon \% Rec 2] 
Exhibit A9. Evaluation of the \% Recovery Values for the First Check Standards

Oneway Analysis of \% Recovery By Instrument First/Second=First

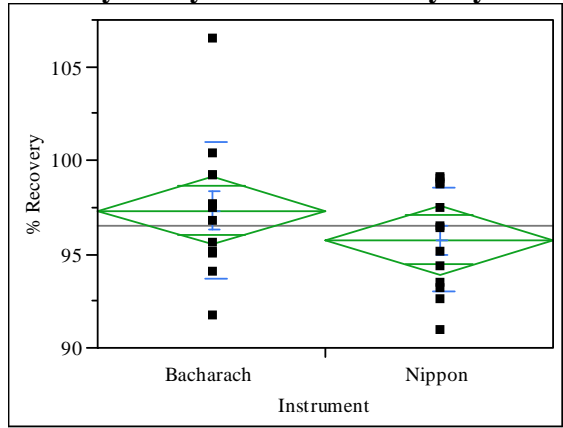

Oneway Anova

Summary of Fit

$\begin{array}{lr}\text { Rsquare } & 0.062073 \\ \text { Adj Rsquare } & 0.022992 \\ \text { Root Mean Square Error } & 3.21388 \\ \text { Mean of Response } & 96.54435 \\ \text { Observations (or Sum Wgts) } & 26\end{array}$

t Test

Nippon-Bacharach

Assuming equal variances

Difference $\quad-1.5887$ t Ratio $\quad-1.26029$

Std Err Dif 1.2606 DF 24

Upper CL Dif 1.0130 Prob $>|t| \quad 0.2197$

Lower CL Dif -4.1904 Prob $>\mathrm{t} \quad 0.8902$

$\begin{array}{lll}\text { Confidence } \quad 0.95 \text { Prob }<\mathrm{t} \quad 0.1098 & \end{array}$

Analysis of Variance

Source DF Sum of Squares Mean Square F Ratio Prob $>$ F

$\begin{array}{llllll}\text { Instrument } & 1 & 16.40595 & 16.4059 & 1.5883 & 0.2197\end{array}$

$\begin{array}{llll}\text { Error } & 24 & 247.89661 & 10.3290\end{array}$

C. Total $25 \quad 264.30256$

Means for Oneway Anova

Level Number Mean Std Error Lower 95\% Upper 95\%

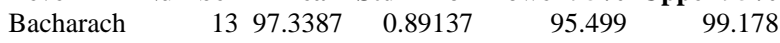

$\begin{array}{lllll}\text { Nippon } & 1395.7500 & 0.89137 & 93.910 & 97.590\end{array}$

Std Error uses a pooled estimate of error variance

Means and Std Deviations

Level Number Mean Std Dev Std Err Mean Lower 95\% Upper 95\%

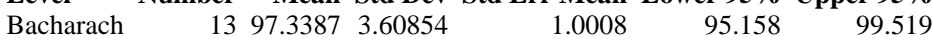

$\begin{array}{llllll}\text { Nippon } & 1395.7500 & 2.76342 & 0.7664 & 94.080 & 97.420\end{array}$

Tests that the Variances are Equal

Level Count Std Dev MeanAbsDif to Mean MeanAbsDif to Median

$\begin{array}{llll}\text { Bacharach } & 13 & 3.608543 & 2.492346\end{array}$

$\begin{array}{llll}\text { Nippon } & 132.763416 & 2.349231 & 2.315000\end{array}$

Test F Ratio DFNum DFDen p-Value

$\begin{array}{lllll}\text { O'Brien[.5] } & 0.5219 & 1 & 24 & 0.4770\end{array}$

$\begin{array}{lllll}\text { Brown-Forsythe } & 0.0502 & 1 & 24 & 0.8247\end{array}$

$\begin{array}{lllll}\text { Levene } & 0.0335 & 1 & 24 & 0.8563\end{array}$

$\begin{array}{lllll}\text { Bartlett } & 0.8107 & 1 & 0.3679\end{array}$

$\begin{array}{lllll}\text { F Test 2-sided } & 1.7052 & 12 & 12 & 0.3680\end{array}$

Welch Anova testing Means Equal, allowing Std Devs Not Equal

F Ratio DFNum DFDen Prob $>$ F

$\begin{array}{lrrr}1.5883 & 1 & 22.473 & 0.2205\end{array}$ 


\section{Exhibit A10. Evaluation of the \% Recovery Values for the Second Check Standards}

Oneway Analysis of \% Recovery By Instrument First/Second=Second

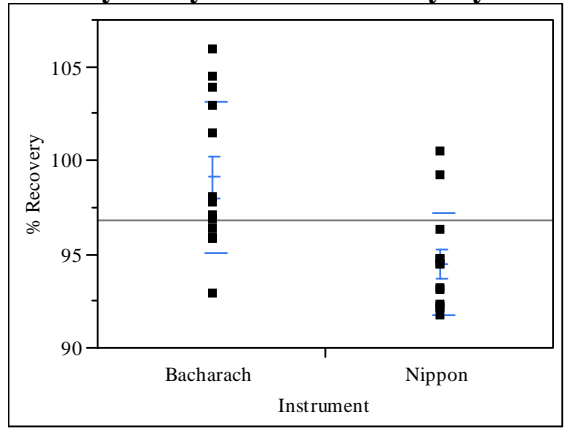

Means and Std Deviations

Level Number Mean Std Dev Std Err Mean Lower 95\% Upper 95\%

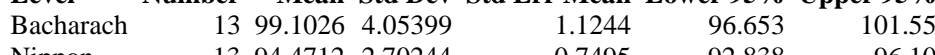

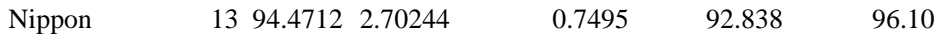

t Test

Nippon-Bacharach

Assuming unequal variances

Difference $\quad-4.6315$ t Ratio $\quad-3.42742$

Std Err Dif $\quad 1.3513$ DF 20.90627

Upper CL Dif -1.8205 Prob $>|t| 0.0025$

Lower CL Dif -7.4424 Prob $>$ t 0.9987

$\begin{array}{lll}\text { Confidence } \quad 0.95 \mathrm{Prob}<\mathrm{t} \quad 0.0013 & \end{array}$

Tests that the Variances are Equal

Level Count Std Dev MeanAbsDif to Mean MeanAbsDif to Median

$\begin{array}{llll}\text { Bacharach } & 134.053989 & 3.496019 & 3.231231\end{array}$

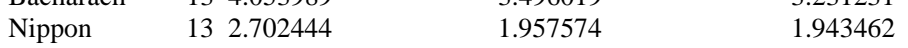

Test F Ratio DFNum DFDen p-Value

$\begin{array}{lllll}\text { O'Brien[.5] } & 2.7022 & 1 & 24 & 0.1132\end{array}$

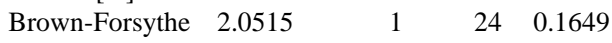

$\begin{array}{lllll}\text { Levene } & 4.8485 & 1 & 24 & 0.0375\end{array}$

$\begin{array}{lllll}\text { Bartlett } & 1.8449 & 1 & \text {. } & 0.1744\end{array}$

$\begin{array}{lllll}\text { F Test 2-sided } & 2.2504 & 12 & 12 & 0.1744\end{array}$

Welch Anova testing Means Equal, allowing Std Devs Not Equal

F Ratio DFNum DFDen Prob > F

$\begin{array}{lrrr}11.7472 & 1 & 20.906 & 0.0025\end{array}$ 


\section{Distribution:}

\begin{tabular}{|c|c|}
\hline Name: & Location \\
\hline Sharon Marra & 773-A \\
\hline Connie Herman & 999-W \\
\hline Charles J. Coleman & 773-A \\
\hline Clint Gregory & 773-A \\
\hline Lori Chandler & 773-A \\
\hline Patricia Lee & $703-41 \mathrm{~A}$ \\
\hline Gene Shine & 703-41A \\
\hline Damon R. Click & 773-A \\
\hline L. Curtis Johnson & 773-A \\
\hline Michael Stone & 999-W \\
\hline David Peeler & 999-W \\
\hline Tommy Edwards & 999-W \\
\hline Kevin Fox & 999-W \\
\hline Fabienne Johnson & 999-W \\
\hline Charles Crawford & $773-42 \mathrm{~A}$ \\
\hline David Best & 999-W \\
\hline John Occhipinti & $704-S$ \\
\hline Jonathan Bricker & $704-27 \mathrm{~S}$ \\
\hline John Iaukea & 704-30S \\
\hline Aaron Staub & $704-27 \mathrm{~S}$ \\
\hline Jeff Ray & $704-S$ \\
\hline Robert Hinds & $704-S$ \\
\hline Terri Fellinger & $704-26 S$ \\
\hline Michael J. Hart & $210-S$ \\
\hline Roger N. Mahannah & $704-28 S$ \\
\hline Michael T. Feller & $704-28 S$ \\
\hline Omar Cardona-Quiles & $704-24 S$ \\
\hline Amanda Shafer & $704-27 \mathrm{~S}$ \\
\hline Mason Clark & $704-27 \mathrm{~S}$ \\
\hline Helen Pittman & $704-27 \mathrm{~S}$ \\
\hline Hank Elder & $704-24 S$ \\
\hline Bill Holtzscheiter & $704-15 S$ \\
\hline Pat Vaughan & 773-41A \\
\hline
\end{tabular}

